JAMIL HAMADNEH, Ph.D. Candidate ${ }^{1}$

(Corresponding author)

E-mail: jhamadneh@edu.bme.hu

DOMOKOS ESZTERGÁR-KISS, Ph.D. ${ }^{1}$

E-mail: esztergar@mail.bme.hu

${ }^{1}$ Department of Transport Technology and Economics

Faculty of Transport Engineering and Vehicle Engineering

Budapest University of Technology and Economics

Mủegyetem rkp. 3., 1111 Budapest, Hungary
Traffic Planning

Original Scientific Paper

Submitted: 27 Apr. 2020

Accepted: 02 Aug. 2020

\title{
POTENTIAL TRAVEL TIME REDUCTION WITH AUTONOMOUS VEHICLES FOR DIFFERENT TYPES OF TRAVELLERS
}

\begin{abstract}
Autonomous Vehicles (AVS) have been designed to make changes in the travel behaviour of travellers. These changes can be interpreted using transport models and simulation tools. In this study, the daily activity plans were used to study the possibility of increasing the utility of travellers through minimizing the travel time by using AVs. Three groups of travellers were selected based on the benefits that they can obtain when AVs are on the market. The groups are (a) long-trip travellers (b) public transport riders, and (c) travellers with specified characteristics. Each group is divided into one or more scenarios based on the definition of each group and the collected data. A total of seven scenarios were derived from the collected data and simulated twice to include the existing transport modes and the presence of AVs. The simulations were conducted using Multi-Agents Transport Simulation (MATSim) that applies the concept of a co-evolutionary algorithm. MATSim simulates the current plans and the ones where AVs replace all or part of the existing conventional transport modes in the daily activity plans. The results have shown a reduction in the trip time: $13 \%$ to $42 \%$ for group (a), $33 \%$ for group (b), and $16 \%$ to $28 \%$ for group (c) compared with the original trip times. In conclusion, it can be claimed that AVs could reduce the travel time in all cases, which provides benefits for people to increase their utilities.
\end{abstract}

\section{KEYWORDS}

agent-based modelling; autonomous vehicles; activity chains; optimization; MATSim.

\section{INTRODUCTION}

Autonomous Vehicles (AVs) are expected to be on the market soon due to the rapid development of car technology. With the presence of this technology, safety, congestion, comfort, reliability, and the travel time will be changed [1]. Such changes are fewer cars on the road, efficient use of road network, fewer parking spaces, travel time reduction, and an increase in the travelled distances of AVs compared with conventional cars [2,3]. On the other hand, this technology will motivate the transport land-use planners to restudy the space distribution based on the assumption that fewer parking spaces are needed for AVs. The AV travellers can reduce the travel time compared to conventional car travellers, because the time spent on the parking process, and the time spent on walking to reach a transport mode will be minimized $[4,5]$. Generally, as a policy, using public transport is recommended over other transport modes, because it alleviates the severity of congestion on the road network due to its large capacity compared with other modes of transport. It is worth mentioning that public transport coverage and accessibility are limited due to the high accompanied infrastructure and operational costs. Thus, people who are more willing to use public transport, use different transport modes in the areas that lack public transport or where public transport is not easily accessible. Some people use multimodal transport to reach their destinations; for example, they use either cars, bicycles, taxis, walking, or scooters to the nearest station/stop of public transport in order to switch to a more comfortable transport mode based on their preferences. The purpose of using mainly public transport is avoiding traffic congestion, parking fees, delay, and tiring travel. The AVs will improve the movements of people because the requirements of this technology are different from conventional ones; for example, no driving license is needed to use AV. Moreover, there are classes of people who face difficulties to travel, such as peo- 
ple who own a car and do not use it because they get tired from driving, people who want to shift to personal car but they cannot, people with different abilities, and elderly people [6]. The proposed users of AVs are people who accept sharing strategy, conduct on-board activities, and want to reduce the travel time. In the meantime, travellers use a car-sharing service in dense urban areas compared with personal cars [4]. However, one problem with this service is the scarcity of parking spaces that consumes time and cost, especially in the case of free-floating car-sharing systems $[4,5]$. It would be clear from the characteristics of AVs that the problem of the car-sharing system is solved by AVs, since $\mathrm{AV}$ parks itself or drives to serve another passenger [4]. The envisaged benefit of AVs is realized when conventional transport modes are partially or fully replaced by AVs. People shift to a new transport mode based on their preferences and the obtained proposed benefit of changes. In the literature, certain groups of people who are more likely to use AVs than others are presented, like long-trip travellers $[6,7]$, public transport riders [8], due to the reduction of the value of travel time when AVs are used [9]. The previous studies mentioned several groups of travellers based on some parameters, like travelled distance, travel time, and value of travel time. In this regard, the assumption that all people are candidates to use $\mathrm{AVs}$ is valid, but certain groups of people are more likely to use AVs than others based on their preferences, individual and trip characteristics, such as special trips (i.e. business), long-distance travellers, personal car users, public transport riders, and travellers with non-frequent travel. This paper includes an assessment of the impacts of $\mathrm{AVs}$ on specific mobility-related measures of three certain groups of travellers based on the literature and the conducted survey in Budapest [10]. The assessment includes the obtained benefit when travellers replace the conventional transport modes partially or fully by AVs.

To understand the impact of AVs on travellers' behaviours, two parts of daily activities should be understood and they are the travel time and the activity time. The travel time represents the time spent in travelling to and from an activity, and activity time represents the time when travellers conduct a stationary activity [11]. These two parts are called the daily activity plan, when a traveller tries to increase the productive part (i.e. activity time), and decrease the unproductive one (travel time) [12]. In this regard, the travellers' daily activity plans can be converted to scores, which reflect both the travellers' preferences and trip characteristic utilities, and these scores need to be maximized [11]. The valuation of both parts of the daily activity plan is based on some parameters, like the marginal utility of travel time, the marginal utility of cost, and the travellers' characteristics [11]. People with different characteristics, like socio-demographic ones, evaluate the travel time differently; for example, some car users evaluate the travel time higher than the public transport users. Additionally, the Value of Travel Time (VOT) is not fixed over time or with all cases, because it depends on several factors related to travellers' preferences and trip characteristics, like a trip purpose $[9,13]$. The travellers try to minimize the VOT by converting part of the travel time to a productive time by conducting on-board activities or using more comfortable transport modes [9]. Horni et al. (2016) stated that the optimization of activity plans of travellers compromises maximizing the activity utility, and minimizing the travel disutility [11].

The contributions of this research are: (1) evaluating the impact of AVs on three different groups of people through seven scenarios; (2) finding the optimal fleet sizes of AVs that are needed to serve the demand in each scenario; (3) examining further factors that impact the change in the travel time in the AVs era. The previous studies mentioned some groups of people who are more likely to use the $\mathrm{AVs}$, and this study simulated those groups to evaluate the impact of the AVs on them. The selected groups were derived from the collected data, while more groups can be selected based on the available data. The outputs of this research present the insight about the implications of AVs on certain groups of travellers, and to be continued to include further groups based on a robust study, such as the stated preference surveys, and empirical pilot studies. This is the first study of its kind that addresses the impacts of AVs on the travel behaviour of people by an agent-based simulation. A sample size in Budapest which contained daily activity plans of travellers were simulated using Multi-agent Transport Simulation (MATSim). The simulations were conducted for three groups: (a) long-trip travellers; (b) public transport riders; (c) travellers with specific characteristics. Seven scenarios were simulated in the three groups; the first group includes three scenarios, the second group includes one scenario, and the third group includes three scenarios, as illustrated 
in the methodology section. In each scenario, both optimization of AVs fleet size and travellers' daily activity plans were carried out to evaluate the impact of AVs on the travel time and distance (utility of travel time was minimized, and utility of activity time was maximized).

\section{LITERATURE REVIEW}

The traveller's behaviour can be changed in the autonomous vehicle era. The cost and time of travel, waiting time, and willingness to share a transport mode are the main determinants of using AVs. Some negative impacts of the travel can be eliminated when AVs are used, such as and not limited to seat availability, safety, comfort, congestion, driving license, driver, and accessibility [1]. The utility value when AVs are used will be generally higher than conventional cars because the travel time onboard AVs can be utilized more than conventional cars, for instance, AV drives without assistance from a traveller, and $\mathrm{AV}$ will come to the location to pick up a traveller. Continuous advancement in transportation exists to ease the life of people and to mitigate the negative impact of mobility. The travellers initiate trips with specific purposes and plan their travel based on their needs. Generally, knowing the travellers' daily activity plans is useful for planners and decision-makers to understand the distribution of travellers over the network and their variations. Studying the daily activity plans of certain groups of travellers, who have certain trip characteristics are required to assess the impact of AVs on their travel behaviour. Particular groups were simulated with AVs in the literature, to assess the changes in travel behaviour compared with conventional transport modes, for example, high-income groups [9].

Meanwhile, Autonomous Vehicles (AVs) have become a hot topic for several stakeholders, like car manufacturers, city planners, travellers, and researchers [14]. The travellers' adaptation with AVs depends on how a traveller can perceive the AV service based on their preferences and the trip characteristics [15]. Cost and time are factors that can affect the use of AVs, while other embedded factors can be also realized, like conducting activities on-board, safety, and comfort. Some scholars have studied the effects of AVs on the mobility of travellers, and on those who would use this new type of vehicle. Hao and Yamamoto (2017) conducted a stated-preferences study to investigate the intentions of people regarding AVs [16]. The results of the study were that $20-30 \%$ of travellers would switch to AVs, and the travellers who work part-time were more likely to switch to AVs. Krueger et al. (2016) stated in their study that elderly people, retirees, or people without a driving license can be potential users of AVs [1]. Das et al. (2017) prepared a study to find who was more likely to use AVs. They concluded that the traveller groups who can benefit from using AVs are long-term commuters who use cars as drivers, transit users, and elderly people [6]. It was found that people would prefer using AVs to reach an activity other than home, instead of using other conventional modes of transport, and those riders were first-class train riders [8]. This study demonstrates that an extra gained benefit is obtained when multimodal travel (AVs plus train) is used compared with using a personal car because travellers will not waste their time on the parking process (time and cost) [8].

Bischoff and Maciejewski (2016) studied the impact of AVs on the existing private cars of Berlin [17]. The results showed that one autonomous vehicle replaces ten conventional taxis, in the case of shared rides, and six in the case of unshared rides [17]. They also concluded that the replacement of conventional cars (1.1 million) could be done by 100,000 autonomous taxis at a high quality of service [17]. Fagnant et al. (2015) concluded that one Shared Autonomous Vehicle (SAV) replaces 9.3 personal cars in the conducted simulation of Austin city. They assumed that all transport modes do not exist and the demand is met by only SAVs. Their methodology included dividing the city into blocks, where each block had a certain number of SAVs to transport only the travellers in that block in order to reduce the waiting time and the Vehicle-Miles-Travelled (VMT) [18]. The SAVs in each block gave priority to the travellers in that block, and in case the demand is met, the stopped SAVs were used to serve the supply shortage of the adjacent block [18]. Therefore, the results demonstrated that the produced reduction in the waiting time by $82 \%$ is due to the used method in locating SAVs inside the city [18]. Moreover, another study by Fegnant and Kockelman addressed the benefits of autonomous vehicles (safety, travel time reduction, and reduction in parking spaces), obstacles to implementation (AVs' cost, certification, liability, security, insurance, and privacy), and some policy recommendations that include mainly continuity of studies and guideline development for AVs [19]. One AV can 
replace four conventional cars and a study conducted in Hungary showed that the workers and shoppers who use park-and-ride system, would use AVs instead of their conventional cars [20,21].

It was mentioned in some literature that $\mathrm{AVs}$ will probably improve the travel environment, such as Steck et al. (2018) who said that in case of using AVs a travellers have the opportunity to conduct some activities on-board that consequentially decrease the value of travel time (VOT) [9]. They demonstrated that the Value of Travel Time Savings (VTTS) when AVs are used, is higher than in the case of SAVs. Moreover, they concluded that high-income travellers have higher VTTS than low-income travellers regardless of which transport mode is used (conventional mode, AVs, or SAVs). Litman (2009) studied the VOT for certain group users, such as high-income, pensioners, children, and employed people [22]. The result of his study demonstrated that as the income increases, people are more likely to pay for saving the travel time. He concluded that the first $20-40$ minutes of travel is to be accepted as non-unpleasant travel, while over 40 minutes may cause problems for travellers, like boredom, frustration, inconvenience, and discomfort. In addition to the above, Bozorg and Ali (2016) in their literature study said that AVs will decrease the VOT of high-income people by $35 \%$ [23].

One common software which has been used in simulating the daily activity plans of travellers is the Multi-agent Transport Simulation tool (MATSim). Technically, MATSim is a software that can be used to simulate a large number of daily activity plans up to $10^{7}$, in a competitive time compared to other software [11, 24]. MATSim applies the concept of a co-evolutionary algorithm based on a built-in utility function that considers the value of time as a reference in scoring. The used utility function combines travel time and travel cost that are accompanied with a plan (travelling and activity times). This utility function is defined in the MATSim loop, in the scoring step, where each plan takes a score after each iteration is selected by a traveller based on the produced score (Logit Model) [11].

As added value to previous literature, this study will assess the impact of AVs on certain groups of travellers, and make a comparative analysis between the existing condition and when AVs are used. The travellers of long trips, public transport users, and travellers with specified characteristics (who are more likely to use AVs) are simulated and presented in this paper.

\section{METHODOLOGY}

This section includes data collection and data analysis subsections. Firstly, the data collection consists of several features, such as population, transit network (stops, lines, and schedules), and road network (links, nodes, and operational parameters) that are required to simulate the daily activity plans of certain travellers, as well as to study some mobility indicators. Secondly, the data analysis illustrates the methodology that will be followed in simulating the travellers in all scenarios, as well as how the utility of travellers was optimized. In this paper, the simulation has been carried out for three groups of users, (a) long-trip travellers, (b) public transport riders, (c) travellers with specific characteristics. Each group contains scenario/s, as shown in Figure 1. The scenarios of group (a) are (1) travellers who travel more than 40 minutes within one trip including the users of all transport modes, (2) travellers who travel more than 40 minutes excluding users of walking and cycling, and (3) travellers who travel at least $10 \mathrm{~km}$ in one trip, regardless of transport mode type. Scenarios of group (b) are (4) AVs as a feeder system from home to the nearest public transport stop, and from public transport stop home

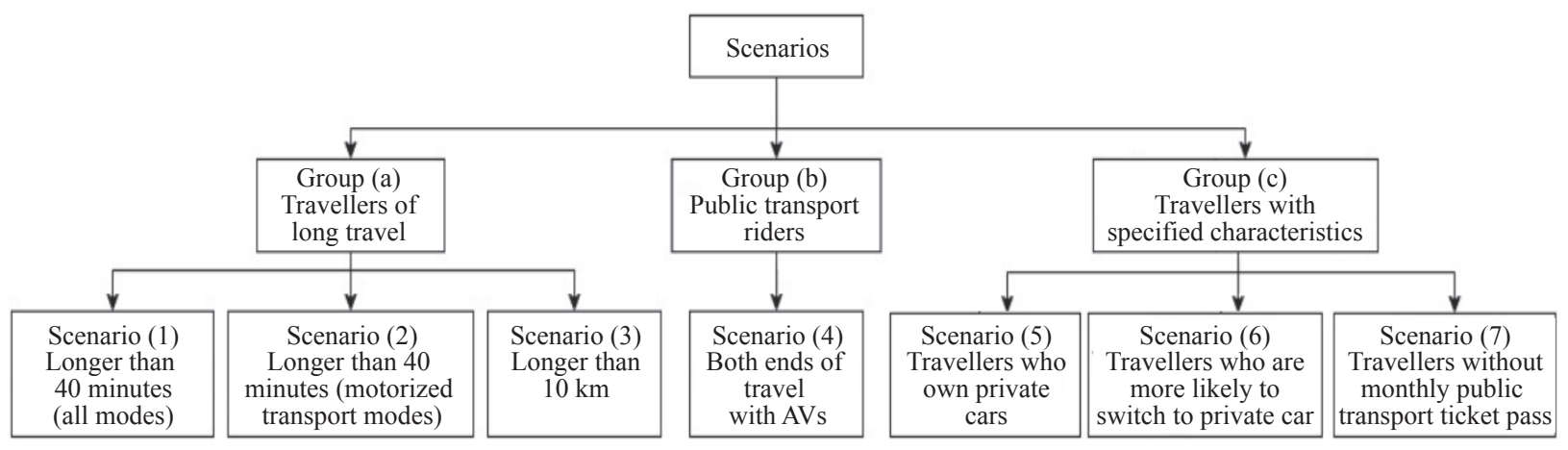

Figure 1 - Proposed travellers'behaviour simulation scenarios 
(feeder system at both ends of travel), and finally, scenarios of group (c) are (5) car ownership travellers, (6) travellers who are more likely to switch to car mode, and (7) travellers who do not have a monthly public transport ticket pass.

Litman (2009) said that the traveller first tends to be uncomfortable when the trip time becomes longer than 40 minutes [22], while Das et al. (2017) mentioned that the potential users of AVs are long-commuters, and long-transit commuters ([6]. Yap et al. (2016) studied the travellers who use a train to reach their destinations [8]. They studied the applicability of using AVs to transport them from the last train stop to their destinations. Based on the wide potential users of $\mathrm{AVs}$, different types of travellers can be attracted by AVs. Those potential users of AVs will have a lower value of travel time compared with their conventional transport modes as stated in the previous studies and derived from the AV characteristics $[9,23,25]$. The value of travel time will decrease by $35 \%$ when $\mathrm{AV}$ is used as mentioned in the study of Bozorg and Ali (2016) [23]. Figure 1 shows some potential users of AVs, and they are summarized in three groups. Group (a) includes all travellers who travelled at least 40 minutes or $10 \mathrm{~km}$ in any trip (the third scenario is based on distance rather than time). The sample sizes of the three scenarios of group (a) are derived from the collected data based on the longest trip time and distance in each traveller's daily activity plan. It is worth mentioning that the sample sizes of all groups are located inside the city. The travel cost of using AVs will be measured for the travel time or travelled distance, and this is reflected in scenarios 1 and 3 to be used in the evaluation and policies by transport and city planners. Group (b) was selected based on the study of Yap et al. (2016) to be used in the future as a replacement technology of personal cars and a feeder system to public transport (intermodal). Last group (c) studied the impact of replacing car ownerships rather than car users as was studied by some researchers because one of the visions of AVs is replacing personal cars and not replacing only cars which are used for commuting. Besides, the collected data include persons who are not feeling well with their current transport modes and who are more likely to switch to personal cars but they cannot; these travellers are suggested to be potential users of AVs. Additionally, people of non-frequent travel who do not buy monthly public transport pass are also assigned to AVs as potential users. These different groups were derived and reassembled from the literature and the collected survey.

\subsection{Data collection}

The data collection in Budapest, Hungary, was carried out by the Hungarian Census Bureau (HCB) in 2014, and HCB conducts a periodic survey every ten years [10]. These data are used in this study that includes socio-demographic variables of travellers and their daily activity plans. In more details the data include mainly the following variables: (1) activity type, (2) trip time, (3) transport mode per trip, (4) departure time, (5) arrival time, (6) employment status, and (7) coordinates of all daily activities. The data include the following activity types: home, work, leisure, education, and others.

From the collected data there were 570 travellers who travelled more than 40 minutes, with 300 travellers who used motorized modes out of 570 travellers and travelled more than 40 minutes, 1,307 travellers who travelled at least $10 \mathrm{~km}$, while 2,000 travellers who used public transport for travelling; 4,042 travellers who own personal cars; 468 persons who wanted to switch to car mode (based on the survey results); and 2,240 passengers who did not have public transport pass (the cost of using transport mode is more expensive than having a monthly ticket, and they are more likely to use AVs because they do not travel in a daily basis based on the collected data). Table 1 presents some statistics about the seven scenarios, and the activity type percentages for each scenario.

\subsection{MATSim simulation tool}

MATSim is an open-source software that can be used to optimize and simulate the activity plans of travellers in a systematic way. In more detail, MATSim can simulate the daily plans of activities at the microscopic-level, since it is defined as a detailed disaggregated microsimulation model, which can capture small details [11]. The MATSim uses a Genetic Algorithm (GA) to generate different activity plans with different utility function values [26]. GA gives a near-optimum solution [27, 28], and the chosen solution is based on the maximum utility that can be obtained from changing the travel parameters (Scoring), such as departure time. The pros of GA over traditional optimization algorithms are the ability to deal with different types of optimization 
Table 1 - Sample size and characteristics of the seven scenarios*

\begin{tabular}{||c|c|c|c|c|c|c|c||}
\hline \multirow{3}{*}{ Travellers'group } & \multirow{2}{*}{ Scenario } & \multirow{2}{*}{ Sample size } & \multicolumn{5}{|c||}{ Activity type [\%] } \\
\cline { 5 - 9 } & & & Work & Education & Shopping & Leisure & Other \\
\hline \hline \multirow{3}{*}{ (a) } & Scenario 1 & 300 & 77.93 & 10.37 & 1.34 & 3.01 & 7.35 \\
\cline { 2 - 9 } & Scenario 2 & 570 & 64.50 & 13.50 & 6.20 & 3.70 & 12.10 \\
\cline { 2 - 9 } & Scenario 3 & 1,307 & 78.25 & 7.66 & 2.45 & 4.52 & 7.12 \\
\hline (b) & Scenario 4 & 2,000 & 61.30 & 13.35 & 12.25 & 1.90 & 11.20 \\
\hline \multirow{2}{*}{ (c) } & Scenario 5 & 4,042 & 53.07 & 18.16 & 12.91 & 2.89 & 12.96 \\
\cline { 2 - 9 } & Scenario 6 & 468 & 79.86 & 7.92 & 2.71 & 2.71 & 6.79 \\
\cline { 2 - 9 } & Scenario 7 & 2,240 & 69.78 & 6.61 & 8.26 & 2.81 & 12.54 \\
\hline
\end{tabular}

* Home-based activity

including stationary and non-stationary, linear, non-linear, continuous, not continuous objective functions [29]. The cons of GA are its sensitivity in the formulation of the objective function, the population size, and the required parameters, such as the rate of crossover and mutation, and the chosen criteria of the new [29]. The results will be meaningless if the selection of the previous points is not properly selected. Scoring of a plan depends on the travel time and travel cost marginal utility (travel time part) parameters, while scoring of an activity depends on the Vickrey bottleneck model parameters. This model considers factors including the marginal utility of travelling and early/late arrival [30]. The data were prepared based on the requirements of MATSim (template, and an XML file), to be consistent with the Java code of MATSim (i.e. the names in the code are the same in the input files). In addition to the population file (activity plans), the population of the case study (Budapest) was taken from the National Hungarian Census $\mathrm{Bu}-$ reau [10], and the points of interest (facilities) were taken from OpenStreetMap (OSM). These points contain information about each facility, like the locations (coordinates), type, and active time (opening hours). OSM with support of JOSP MATSim plugin was used to extract the road network components of Budapest [31]; similarly, public transport network and schedule data were taken from the Centre for Budapest Transport, called BKK [32] in the form of General Transit Feed Specification (GTFS) files, which were converted to an XML file compatible with MATSim requirement [33]. Figure 2 shows the road network and the travellers' locations (i.e. origins and destinations) in the case study. The Budapest city includes 23 districts, more than 190 thousand nodes, and more than 430 thousand links.

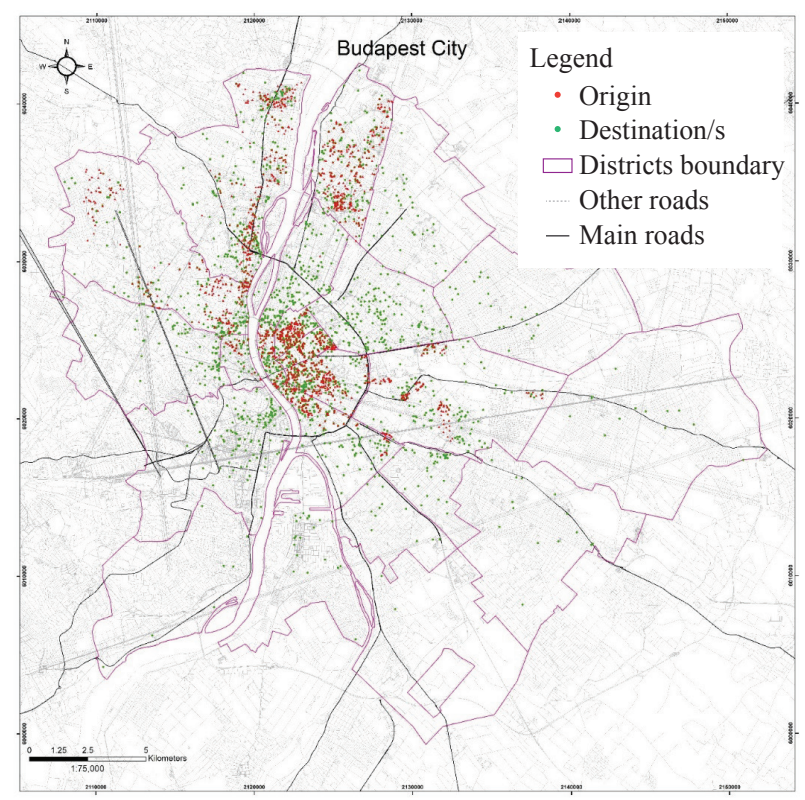

Figure 2-Road network, travellers'locations, and destinations

The data files were combined using MATSim "configuration file" (this file is called by the MATSim code). Practically, the "configuration file" contains several modules, for example, daily activity plans, transit vehicles, a transit network, transit schedules, road network, points of interest, coordinate systems, output folder paths, initial/final iterations, and Mobility Simulation (MobSim) [34]. MobSim reflects the dynamic traffic modelling and uses the queue-based simulation (flow capacity of a link, travel speed, and car-following model) to load the network of initial demand [11]. Moreover, the Queue simulation (Qsim) which is the MATSim's default MobSim is used as a mobility simulator to define the schedule in which a plan is to be executed after both the re-planning process and the scoring parameter steps are performed [11]. 


\subsection{Data analysis}

The collected daily activity plans represent the existing conditions. In this paper, the simulation of the existing condition of activity plans of each scenario was performed first, then the proposed modifications on each scenario were simulated (simulation with AVs). The optimization of the utility function of all cases (the existing and the proposed ones) were conducted. As mentioned earlier, MATSim was used for simulation and aimed to optimize the initial daily plans of each traveller, to make a comparison between the existing condition and the new one (with AVs), as well as to calculate the impact of each scenario on the travellers' mobility.

Each plan goes through some steps to reach a high score based on the Charypar-Nagel utility function [11]. This must be run for many iterations when MATSim is executed. The decision about the number of iterations that must be executed is taken from the output of the MATSim scoring diagram. This diagram shows whether a steady-state equilibrium is reached or not, and whether the score becomes maximum or not yet. Hereafter, some brief descriptions of the three steps of the MATSim loop are as follows.

\section{Mobility simulation (MobSim)}

The collected data contain information about locations of activities, time of departure, time of arriv$\mathrm{al}$, and transport mode. The collected information represents the initial demand while loading this information on the network represents the "MobSim" step. Dijkstra's algorithm is used to assign the best route to each traveller's trip [35]. This can be done based on the departure time and pre-selected transport mode (from the collected data). The assigned plans get a score (iteration 0) based on some related variables, such as travel time, travel cost, travel distance, and time for conducting an activity (see Equation 2). The iteration 0 gets a score, then it goes again for a second loop, where a modification of the plan is executed; for example, changing the route, changing the arrival time, and changing the transport mode. Based on that a new plan is generated with a new score. This process continues until the steady-state of the system or a maximum score is reached. The output of new plans is stored in the events output file. Events are created before and after each step in the MATSim loop [11]. It is worth mentioning that the default mode of the transport in MATSim is conventional car mode, and all other modes are used by defining their operational parameters based on the car transport mode, like distance and time [11]. A "teleportation process", which depends on some parameters written in the "configuration file", enable the Qsim to simulate different modes based on speed factors, distance, and travel time [11].

\section{Scoring (utility function)}

Utility and scoring are synonyms, which can be defined as the process of evaluating each generated plan. Moreover, a comparison of the generated plans can be examined to select the plan of the highest score. The used utility function combines both activity and travel time, which gives a positive value for performing activities and a negative value for travelling from and to activities. The utility of conducting an activity depends on the time of starting an activity; whether it starts late or early, whether there is waiting, the length of stay as well as the operating condition of an activity (opening time). On the contrary, the (dis)utility of the travel for a selected transport mode depends on the time, fees, and travelled distance as illustrated later in Equation 2 [11].

Charypar-Nagel utility function determines the total utility of a plan, as shown in Equation 1 [26]. A traveller's plan means the time distribution between travelling and conducting activities. The benefit of conducting a plan is called utility. The utility of a plan consists of positive utility (conducting an activity), and a negative one (conducting a travel to reach an activity). The sequence of consecutive activities is called the activity chain. Travellers maximize their scoring when they plan their travel; for example, a traveller can minimize the spent time and cost of the travel by choosing a proper departure time and transport mode. For more details about the used utility function in the simulation, see [11].

$U_{(p l a n)}=\sum_{i=0}^{n}\left(U_{(a c t, i)}+U_{(t r a v, i)}\right)$

where $U_{(p l a n)}$ is the utility of performing a plan; $U_{(a c t, i)}$ stands for the utility of performing the activity (positive value); and $U_{(\text {trav, }, \text { })}$ means the disutility derived from travelling to and from an activity (negative value). The first part $U_{(a c t, i)}$ represents the situations when a traveller reaches an activity (performing an activity, a late arrival to an activity, waiting for the activity to open, early departure from the activity, and short duration of the activity), where each situation has its penalty. The $U_{(t r a v, i)}$ represents the travelling part which is considered disutility 
because this time is wasted compared to the productive time in performing an activity. The travel disutility is expressed generally in Equation 2 [11]:

$$
\begin{aligned}
& U_{(\text {trav },(\text { mode }, i))}=C_{(\text {mode }, i)}+B_{\text {trav },(\text { mode }, i)} \cdot T_{\text {trav }, i}+B_{(m)} \Delta_{(m, i)}+ \\
& +\left(B_{(d,(\text { mode }, i))}+B_{m} \cdot \gamma_{(d, \text { mode }, i)}\right) D_{\text {trav }, i}+B_{(\text {transfer })} \cdot x_{(\text {transfer }, i)}
\end{aligned}
$$

where mode stands for a transport mode; $i$ stands for activity; $d$ is the distance; and trav stands for the travel. $C_{(\text {mode }, i)}$ is a mode-specific constant; $B_{\text {trav, (mode, } i)}$ is the marginal utility of travelling; $T_{\text {trav }, i}$ is the travel time from activity $i$ to activity $i+1$; $B_{(m)}$ is the marginal utility of money; $\Delta_{(m, i)}$ is the change rate in the monetary budget caused by fares; $B_{(d,(m, i))}$ is the marginal utility of distance; $\gamma_{(d, m, i)}$ is the mode-specific monetary distance rate; $D_{\text {trav }, i}$ is the travelled distance between activity $i$ and activity $i+1 ; B_{\text {(transfer) }}$ is the public transport transfer penalty; and $x_{(\text {transfer }, i)}$ is to indicate if a transfer occurred in the previous and the current plan ( 0 is no, and 1 is yes). The values of all previous parameters were derived based on the characteristics of the collected data. The model of Budapest was calibrated and the parameters are presented in Table 2, based on the methodology presented by [11, 24, 36, 37].

It is worth mentioning that the MATSim gives default values for some parameters in the case it is difficult to have a unique value for the model. For more further illustration about MATSim utility parameters see $[2,11,36]$. The daily activity plans of travellers go through this utility function $\left(U_{\text {plan }}\right)$ and the result utility is recorded. The MATSim algorithm enables those plans to go through steps to make changes to the plans based on the pre-set innovations. The required innovation types (i.e. modification) on activity chain plan can be done in the "configuration file", where a specific module, called strategy, is used to make modifications on activity chain plans, like changes in the departure time, modes choice and route choice [26]. In the end, MATSim stops changing when the system comes to an equilibrium, where no benefit can be obtained from changing on the travellers' activity plans.

\section{Re-planning}

Travellers in the system try maximizing their plans in every iteration to reach a steady-state condition. This is done in the re-planning step which is known as a learning mechanism in MATSim. A Multinomial Logit (ML) model is used for plan selection after alternatives are generated, and to calculate the probability of using a specific transport mode based on the generated distribution of the utility function [38]. As mentioned in the scoring step, the re-planning step is executed after the scoring step where a modification of a plan is conducted based on the pre-set strategies, for example, activate the rules when to reuse the previous plan, percentage of selected plans to perform changes (change leg mode, re-route, and time allocation).

\subsection{Model implementation}

The first stage of simulation includes simulating the existing conditions, with different types of travellers based on each scenario (see Figure 1). The second stage of simulation is the inclusion of $\mathrm{AVs}$ in the simulation by replacing the current mode of transport, and walking modes at both ends of the current travel to AVs. The results address the comparisons between the current condition and the new one, in terms of travel time, waiting time, travel distance, and AV fleet size.

In the simulation of AVs, the acceptable waiting time for a traveller is around 10 minutes based on the literature. The 10 minutes acceptable waiting time were taken from the literature, where scholars showed that this value is equivalent to an average parking time for car users, and walking time for public transport users [17, 39]. Moreover, some studies showed that people are more likely to wait 5 to 10 minutes without feeling bad or nervous. And it was demonstrated that an acceptable waiting time of 10 minutes can decrease the fleet size of AVs by $90 \%$ [39]. In the simulation, this waiting time value controls the fleet size determination of AVs.

Table 2-Model coefficients

\begin{tabular}{||l|l||}
\hline \multicolumn{1}{||c||}{ Parameter } & \multicolumn{1}{c||}{ Calibrated values } \\
\hline \hline Marginal utility of performing activity- $\beta$ dur & +6 \\
\hline Marginal utility of money $-\beta \mathrm{c}$ & 0.0018 \\
\hline Monetary distance rate (per meter) & -0.40 car, -0.038 PT, -0.004 bike, -0 walking \\
\hline Marginal utility of travelling for all modes $(\beta \mathrm{t})-($ time) & -2.5 car, -0.5 PT, -0.3 bike, -0.1 walking \\
\hline Constant $-\beta \mathrm{o}$ & -0.2 car, 3.92 PT, 2.64 walking, -17.81 bike \\
\hline
\end{tabular}


Initially, a random fleet size is generated on the road network, and this process is repeated several times until an optimal fleet size is determined based on the demand with the plausible waiting time. The results of the simulation each time a new fleet size is selected determines whether to decrease or increase the fleet size, based on the $95^{\text {th }}$ percentile waiting time of travellers [11]. The $95^{\text {th }}$ percentile of waiting time means that a maximum of 95 percent of travellers will be exposed to this amount of waiting time. Besides, the simulation of $\mathrm{AVs}$ requires an algorithm that mimics the behaviour of this new technology. Fortunately, MATSim has a Dynamic Vehicle Routing Problem (DVRP) algorithm which matches the travellers with the same schedule either partially or fully, as presented in the study by Maciejewski \& Nagel (2011), who integrated the DVRP in MATSim [40]. The authors used DVRP Optimizer to solve different versions of DVRP. A memetic algorithm is used by the DVRP Optimizer that includes local search procedure and an evolutionary algorithm for solving the DVRP. The DVRP Optimizer is informed every time a change in the fleet availability or the traffic condition occurs, to make an action (re-route a plan) and send a message to the MATSim about the new route and schedule. A sequential execution of MATSim simulation is required to implement the optimization that assembles the time-dependent travel times and costs (that are taken from MATSim simulation) concerning the supply and demand characteristics [40]. Here, AVs can be used also as shared autonomous vehicles (DVRP module) [11, 41]. The required parameters that must be identified are the capacity of the vehicle (four passengers), the pick-up and drop-off time (120 seconds, and 60 seconds, respectively). These values were chosen based on literature [42]. It is worth mentioning that the initial locations of the AVs are not important since after a few iterations a reallocation of the AVs' concerning the demand locations is performed. Demand Ride-Sharing (DRS) is a built-in algorithm in MATSim, that is used to match travellers with similar routes and within a shared time window [43]. In summary, MATSim is designed to simulate the daily activity plans, when AVs are used.

\section{RESULTS}

This section presents the result of the simulation of the three groups of travellers, where the first group has three scenarios, the second one has one scenario, and the third one has three scenarios, as shown in Figure 1. It is worth mentioning that the simulation of the entire sample size $(8,500)$ showed that the average trip time for all travellers was 33.4 minutes and the average trip distance was $3.9 \mathrm{~km}$. The following subsections present firstly the output of the existing condition, then the result when AVs were used. Moreover, a discussion of each scenario is also presented.

\subsection{Travellers of long-travel group}

In this section, three scenarios are studied, as follows: (1) travellers who travel more than 40 minutes regardless of what mode of transport is used, (2) travellers who travel more than 40 minutes with a motorized mode of transport, and (3) travellers who travel more than $10 \mathrm{~km}$. The used sample sizes are 570, 300, 1,307 travellers for scenarios 1, 2, and 3 , respectively. The simulation of the existing condition (conventional transport modes) of the three scenarios produced average trip distances of $9.3 \mathrm{~km}$, $9.9 \mathrm{~km}$, and $9.2 \mathrm{~km}$. While the average trip times are $43.3,37.3$, and 28.2 minutes for scenarios 1,2 , and 3 , respectively. The simulation of the daily activity plans of scenario 3 produced trip distance smaller than $10 \mathrm{~km}$ because the users of this scenario were selected from the daily activity plans rather than the simulation. Additionally, the travel distances from the activity plans showed that the simulation optimized the travel time and travel distance based on the occurred modifications of route and time allocation strategies in the re-planning step in the MATSim loop. The results of the AVs simulation are shown in Table 3, where the fleet size of AVs is determined by several trials based on the produced $95^{\text {th }}$ percentile waiting time. The $95^{\text {th }}$ percentile of waiting time means 95 percent of travellers will be exposed to this amount of waiting time, maximum. An average waiting time is the arithmetic mean of the waiting time of travellers, empty driven time means the total time when AVs are empty and going to serve a traveller, occupied time is the total time where AVs are occupied by passengers, pick-up time is the time needed for all travellers to get into the vehicle, and drop off time is the time needed for all travellers to get off from the AV. The iterations run of the three scenarios were 300,225 , and 200, respectively.

The average trip times are 14.5, 20.4, and 15.4 minutes, and the average waiting times are 4.7, 4.3, and 3.5 minutes, for scenarios 1,2 , and 3 , 
Hamadneh J, Esztergár-Kiss D. Potential Travel Time Reduction with Autonomous Vehicles for Different Types of Travellers

Table 3 - Travellers'trip time components when AVs fleet size is used per scenario

\begin{tabular}{||c|c|c|c|c|c|c|c|c|c||}
\hline Scenario & $\begin{array}{c}\text { Fleet } \\
\text { size }\end{array}$ & $\begin{array}{c}\text { Average trip } \\
\text { time }\end{array}$ & $\begin{array}{c}95^{\text {th }} \text { percentile of } \\
\text { waiting time }\end{array}$ & $\begin{array}{c}\text { Average } \\
\text { waiting time }\end{array}$ & $\begin{array}{c}\text { Empty } \\
\text { driven time }\end{array}$ & $\begin{array}{c}\text { Occupied } \\
\text { time }\end{array}$ & $\begin{array}{c}\text { Pick-up } \\
\text { time }\end{array}$ & $\begin{array}{c}\text { Drop-off } \\
\text { time }\end{array}$ \\
\hline & & \multicolumn{5}{|c|}{ Minutes per trip } \\
\hline 1 & 120 & 14.5 & 10.6 & 4.7 & 88.4 & 286.9 & 38 & 19 \\
\hline 2 & 70 & 20.4 & 10.2 & 4.3 & 25.6 & 117.8 & 11.9 & 5.9 \\
\hline 3 & 300 & 15.4 & 9.03 & 3.5 & 151.9 & 762.6 & 87.2 & 43.6 \\
\hline
\end{tabular}

respectively. While 9.03, 10.6 and 10.2 minutes are the $95^{\text {th }}$ percentiles of Scenarios 1, 2, and 3, respectively. From Table 3, the ratio between empty time and occupied time for each scenario is calc sulated, and they are $31 \%, 22 \%$, and $20 \%$ for Scenarios 1 , 2 , and 3 , respectively. These ratios mean that the travelled distance of $\mathrm{AVs}$ is higher than the conventional transport mode by those percentages. It is worth mentioning that the numbers in the last four columns in Table 3 are related to the fleet size and are not related to an individual vehicle or a traveller. For example, the occupied time in scenario one means that the total travel time for 570 travellers to conduct their daily activities is 289.9 hours, while the time for picking up all travellers is 38 hours, and dropping the travellers off is 19 hours. Figure 3 and Figure 4 depict examples of the time profile of AVs serving the travellers in scenario 2, and scenario 3, the two peak periods are shown, which are around 6:30-9:00 and 16:00-18:00. Generally, the peak periods give an indication of the distribution of travellers over time, as this time gets narrow, many AVs are required to serve the demand. The largest number of travellers in peak periods determines the fleet size of $\mathrm{AVs}$, in addition to what has been explained earlier.

\subsection{Travellers who use public transport mode group}

In this section, Scenario 4 was conducted. This scenario contains 2,000 daily activity plans of travellers, who use public transport. This scenario aims to compare the mobility indicators when $\mathrm{AVs}$ are used as a feeder system from the location of an activity to a public transport stop and vice versa (feeder mode for public transport), which means walking distance, will be traversed realized by AVs rather than walking. The simulation of the existing condition (i.e. public transport mode with walking for access and egress distances) produces average trip distances of $1.8 \mathrm{~km}$. While the average trip time was 26.2 minutes. The travel time and travel distances are optimized based on the occurred modifications in route and time allocation strategies in the re-planning step in the MATSim loop. The results of the simulation with AVs are shown in Table 4, where the determination of the fleet size of AVs was optimized by making several runs, and checking the produced $95^{\text {th }}$ percentile waiting time. Around 13.24 minutes is the average trip time, while 3.6 minutes is the average waiting time, and 10.9 minutes is the $95^{\text {th }}$ percentiles. From Table 4, the ratio between empty time and occupied time is 78 percent. This large percentage is a result of the distribution of demand, and the departure time of travellers. This ratio means that the AVs travelled much longer distances than in the existing condition, to pick up and drop off travellers. It is worth mentioning that the numbers in the last four columns in Table 4, are for fleet size and not for an individual vehicle or a traveller. For example, the occupied time means that the total travel time for 2,000 travellers to get access to and egress from public transport stops is 454.8 hours, while the time for picking up all travellers is 195 hours, and dropping off the travellers is 97.5 hours. The results of simulation produced a modal split including walking mode, access and egress time, and public transport. The walking mode remained to some extent because the AVs cannot

Table 4 - Travellers'trip time components when the fleet size of 425 SAVs was used

\begin{tabular}{||c|c|c|c|c|c|c|c|c||}
\hline Scenario & $\begin{array}{c}\text { Fleet } \\
\text { size }\end{array}$ & $\begin{array}{c}\text { Average trip } \\
\text { time }\end{array}$ & $\begin{array}{c}95^{\text {th }} \text { percentile of } \\
\text { waiting time }\end{array}$ & $\begin{array}{c}\text { Average } \\
\text { waiting time }\end{array}$ & $\begin{array}{c}\text { Empty } \\
\text { driven time }\end{array}$ & $\begin{array}{c}\text { Occupied } \\
\text { time }\end{array}$ & $\begin{array}{c}\text { Pick-up } \\
\text { time }\end{array}$ & $\begin{array}{c}\text { Drop-off } \\
\text { time }\end{array}$ \\
\hline & & \multicolumn{5}{|c|}{ Minutes per trip } \\
\hline \hline 4 & 425 & 13.2 & 10.9 & 3.6 & 354.6 & 454.8 & 195 & 97.5 \\
\hline
\end{tabular}




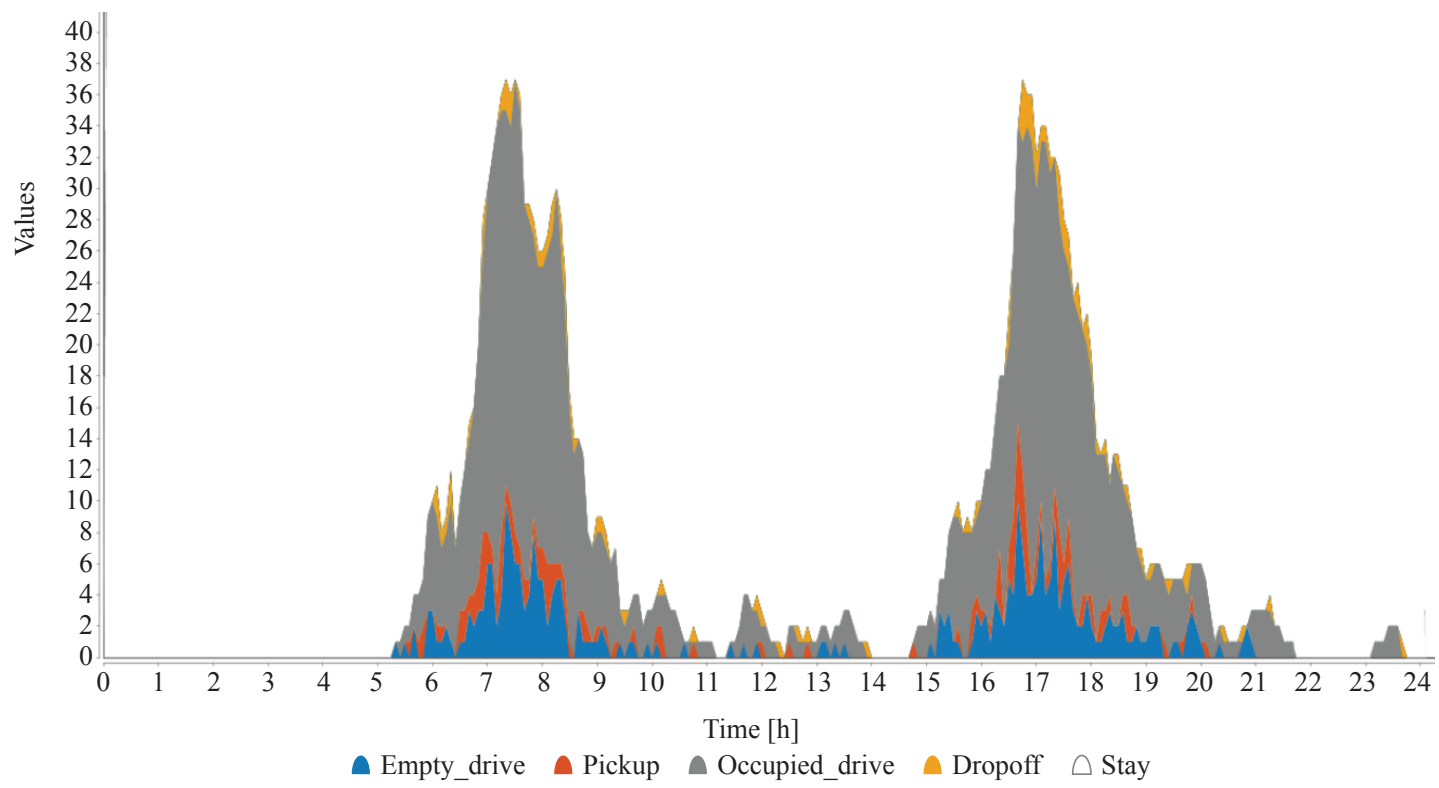

Figure 3 - Time profile of AVs of Scenario 2

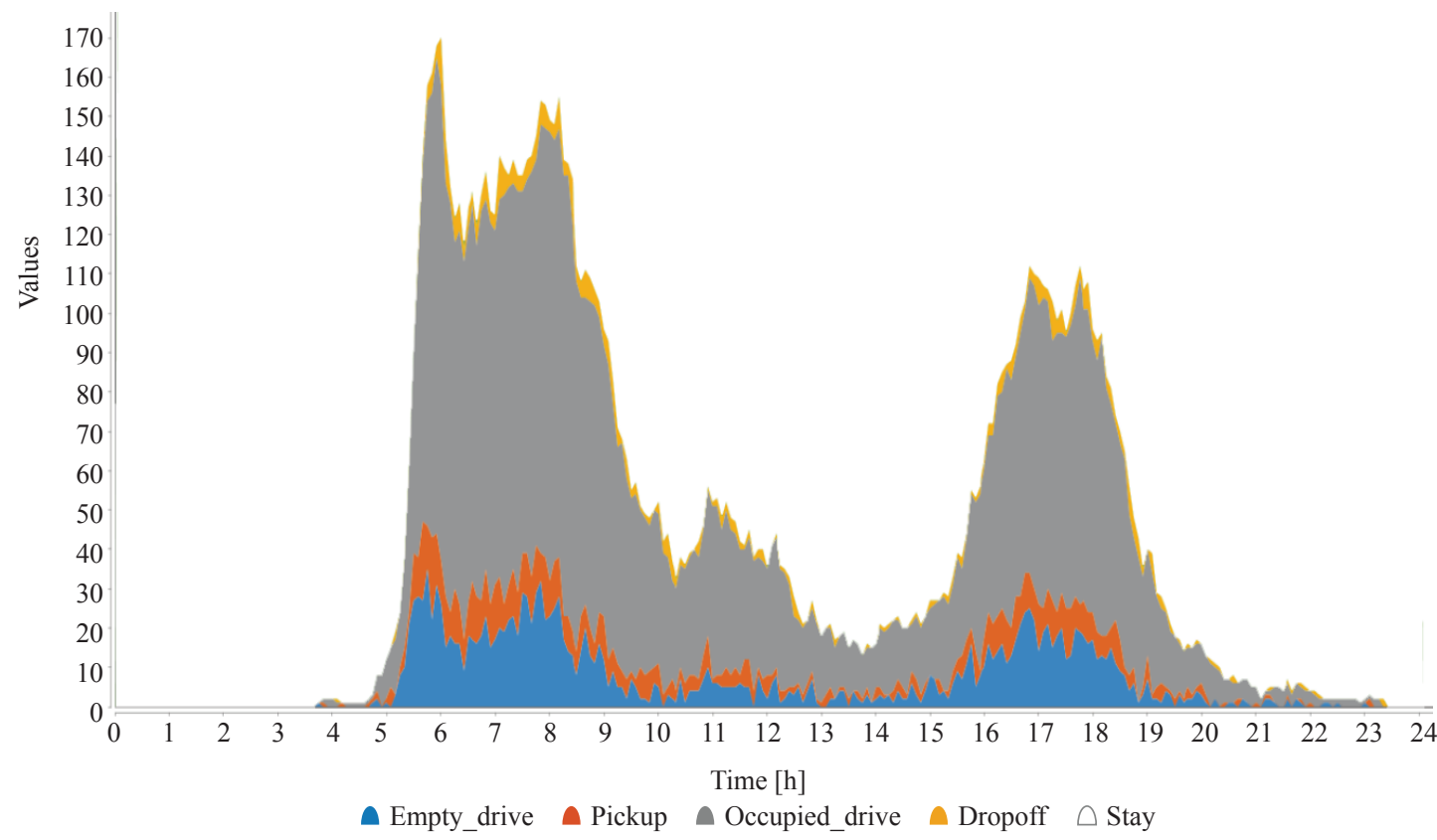

Figure 4 - Time profile of AVS of Scenario 3

access the exact location of some travellers, based on the results of the simulation. The iteration runs of the scenario were 500 .

\subsection{Travellers with specified characteristics group}

Based on the characteristics of travellers, three scenarios were selected to be studied and compared with the corresponding transport modes. Scenario 5 included travellers with car ownership, i.e. all people who own a personal car, regardless of whether they used it partially or not when they conducted their daily activity plans. Scenario 6 includes travellers who were not satisfied with their current transport mode and wanted to switch to car mode. Scenario 7 includes people who do not have a public transport ticket pass and are more likely to use other transport modes, where the cost of using public transport is relatively costly compared to those who own a monthly ticket. As in previous groups, simulation of the existing condition of Scenarios 5, 6, and 7 were carried, followed by simulations of AVs for each 
Table 5 - Travellers' trip time components when the fleet size of AVs is used per scenario

\begin{tabular}{|c|c|c|c|c|c|c|c|c|}
\hline Scenario & $\begin{array}{l}\text { Fleet } \\
\text { size }\end{array}$ & $\begin{array}{l}\text { Average trip } \\
\text { time }\end{array}$ & $\begin{array}{l}95^{\text {th }} \text { percentile of } \\
\text { waiting time }\end{array}$ & $\begin{array}{c}\text { Average } \\
\text { waiting time }\end{array}$ & $\begin{array}{c}\text { Empty } \\
\text { driven time }\end{array}$ & $\begin{array}{l}\text { Occupied } \\
\text { time }\end{array}$ & $\begin{array}{l}\text { Pick-up } \\
\text { time }\end{array}$ & $\begin{array}{l}\text { Drop-off } \\
\text { time }\end{array}$ \\
\hline & & \multicolumn{3}{|c|}{ Minutes per trip } & \multicolumn{4}{|c|}{ Vehicle-hours per day } \\
\hline 5.1 & 650 & 14.1 & 9.5 & 3.1 & 319.9 & $1,239.5$ & 206.8 & 103.4 \\
\hline 5.2 & 850 & 10.5 & 9.1 & 2.7 & 359.5 & $1,501.7$ & 269.9 & 134.9 \\
\hline 6 & 150 & 14.1 & 10.4 & 3.6 & 55.5 & 201.5 & 30.9 & 15.4 \\
\hline 7 & 475 & 12.1 & 9.8 & 3.5 & 257.8 & 964.1 & 149.4 & 74.7 \\
\hline
\end{tabular}

scenario. Specifically, Scenario 5 is divided into two sub-scenarios. Sub-scenario 5.1 includes the currently used transport modes and Sub-scenario 5.2 is built based on the assumption that all travellers would use their cars. In the simulation with AVs, Sub-scenario 5.1 contains the daily activity plans of travellers where AVs are used instead of the existing motorized modes, to compare with the existing condition, while Sub-scenario 5.2 is simulated in a way, where all modes of transport are replaced by AVs in the daily activity plans of travellers. The result of the existing condition simulation for Scenarios 5.1 and 5.2 is $4.2 \mathrm{~km}$ and $5.7 \mathrm{~km}$, respectively, while the average trip time is 31.2 minutes and 23.2 minutes, respectively. Moreover, the average trip distance for Scenarios 6 and 7 is $2 \mathrm{~km}$ and $7.3 \mathrm{~km}$, respectively, while the trip time is 34.1 minutes and 27.1 minutes, respectively. Table 5 presents the required fleet size of each scenario, for example, Scenario 6 requires 150 vehicles to meet the demand. Additionally, the average trip time, $95^{\text {th }}$ percentile of waiting time, average waiting time, and the conditions of the AV fleet (empty driven, picking up/dropping off travellers, occupancy of passengers) is presented for each scenario. From Table 5, the ratio of empty time and the occupied time determines the amount of extra travelled distance compared to conventional transport modes. For example, AVs of Scenarios $5.1,5.2,6$, and 7 travelled $25.8 \%, 23.9 \%, 27.5 \%$, $26.7 \%$ more in terms of distance compared with the conventional transport mode, respectively. The iteration runs of the three scenarios were 300,200 , and 200 , respectively.

\section{DISCUSSION}

The resulting average trip time is not the same as the average total travel time for the daily travel of a traveller. The average total travel time is calculated by multiplying the average number of trips in all activity plans of travellers by the generated average trip time. The trips time and travel distances were minimized based on the simulation of the existing conditions because MATSim optimized the travel time and distance by assigning the best route and allocating the best time for each activity. This means that travellers can increase their daily utility when they travel for conducting their daily activities. The simulation with AVs produced attractive results, where the travel time was less than the resulted travel time of the existing conditions for all scenarios. But it must be noted that AVs will travel more distance than conventional transport modes, which is considered an unfavourable impact, especially on the environment and on the infrastructure. Table 6 shows the comparison between the results of AVs and conventional modes, based on the seven scenarios.

Most of the population (95\%) will experience waiting times around ten minutes based on the optimized AV fleet, which is consistent with the acceptable waiting time mentioned in the literature. The last column of Table 6 presents the obtained reduction in trip time when AVs were used. The reduction in travel time (including the $95 \%$ waiting time) was $13 \%$ to $42 \%$ for group (a), $33 \%$ for group (b), and $16 \%$ to $28 \%$ for group (c). These reductions were estimated based on the results of the simulations. In the meanwhile, the parking process time (i.e. searching time, and parking time) for travellers who park their cars, were calculated based on the composition of the collected data (i.e. not all travellers used their cars in the existing condition, or in other words, modal split). Thus, the results showed more time to be saved when AVs are used because the simulations of the existing conditions did not include the parking time. The consumed time in the parking process corresponds to the acceptable waiting time for $\mathrm{AVs}$ (ten minutes).

It can be derived from the obtained results that using $\mathrm{AVs}$ reduced the travel time in all scenarios. The amount of reduction depends on the fleet size 
Hamadneh J, Esztergár-Kiss D. Potential Travel Time Reduction with Autonomous Vehicles for Different Types of Travellers

Table 6 - Trip time comparison between conventional modes and AVS

\begin{tabular}{|c|c|c|c|c|c|c|}
\hline \multirow{2}{*}{ Group } & \multirow{2}{*}{ Scenario No. } & \multicolumn{3}{|c|}{ Autonomous vehicles } & \multirow{2}{*}{$\begin{array}{c}\text { Conventional } \\
\text { modes }\end{array}$} & \multirow{2}{*}{$\begin{array}{l}\text { Time-saving } \\
{[\mathrm{min}]^{*}}\end{array}$} \\
\hline & & AVs fleet size & $\begin{array}{c}95^{\text {th }} \text { percentile passenger } \\
\text { waiting time [min] }\end{array}$ & $\begin{array}{l}\text { Average trip } \\
\text { duration [min] }\end{array}$ & & \\
\hline \multirow{3}{*}{ (a) } & 1 & 120 & 10.6 & 14.5 & 43.3 & 18.2 \\
\hline & 2 & 70 & 10.2 & 20.4 & 37.3 & 6.7 \\
\hline & 3 & 300 & 9.0 & 15.4 & 28.2 & 3.8 \\
\hline (b) & 4 & 425 & 10.9 & 13.2 & 36.2 & 12.0 \\
\hline \multirow{4}{*}{ (c) } & 5.1 & 650 & 9.5 & 14.1 & 31.2 & 7.6 \\
\hline & 5.2 & 850 & 10.5 & 9.1 & 23.2 & 3.6 \\
\hline & 6 & 150 & 10.4 & 14.1 & 34.1 & 9.6 \\
\hline & 7 & 475 & 9.8 & 12.1 & 27.1 & 5.2 \\
\hline
\end{tabular}

* Individual saving per trip

of AVs (i.e. smaller AVs fleet size means longer trip time, and longer waiting time), and the characteristics of travellers (activity locations, transport mode, activity time). It can be noted that as the percentage of motorized transport modes increases in the daily activity plans of travellers, the reduction in travel time decreases. The seven scenarios demonstrated the benefits of using AVs, in terms of travel time, waiting time, and travel distance. While, other benefits can be also obtained when AVs are used, such as converting part of the travel time into productive time through conducting on-board activities (multitasking). Moreover, AVs would provide safety, comfort, and high accessibility more than conventional transport modes, because AVs do not have human behaviour mistakes. In the era of $\mathrm{AVs}$, the locations of activities are more likely to be expanded because AVs have high accessibility, since these cars drive by themselves, and the travellers will consider changing their home location in the AV era. From the obtained results mentioned in Table 6, the fleet size of AVs, which is less than the number of travellers, served all the demand. In the assumption where each traveller used their conventional cars, the number of conventional cars needed to serve the demand was larger than the AV fleet size. This implied that one AV can replace more than one conventional car (see Scenario 5, for example), and as was mentioned in Hamadneh and Esztergár-Kiss's study [36].

All scenarios showed an increase in the travelled distance, and this increase has consequences like air pollution, which was demonstrated also in literature [44]. On the contrary, other scholars showed a decrease in air pollution, and this conclusion is based on the decrease in the vehicle-kilometre-travelled in the presence of car-sharing service which are similar to the AV service $[45,46]$. The automotive industries are walking toward clean energy, so hybrid and electric cars are available nowadays. Thus, the problem of air pollution can be solved by using clean energy instead of internal combustion engines. Additionally, the result of this study showed a noticeable decrease in the travel time based on the simulation of the existing situations, and the study did not consider the changes in the behaviour of people when the life becomes easier (AV era). For example, more trips will be generated, and this was demonstrated in [44]. Simoni et al. (2018) said that the capacity of the road will increase in the AV era by $150 \%$, which means the roads will have the opportunity to take more AVs per lane [38]. While Calvert et al. (2017) said that the capacity of roads increases when the penetration of the AVs is higher than 70\% [47]. The increase in the capacity of roads will motivate people to conduct more trips. The obtained benefit from Scenario 4 can be misused by an operator to make more profit, so the transport planners must find a strategy to control that by defining the work zones of AVs with respect to the nearest public transport stops. Therefore, the legislation and the policies that can govern and control the negative impacts of using AVs need to be studied.

Particularly, the results of this study can be changed based on the used road network, public transport network and schedule, and the composition of daily activity plans (distribution of departure and arrival times, mode split, locations of activities). 


\section{CONCLUSION}

Recently, the concept of AV has appeared, and this new technology will provide some kinds of solutions for the parking spaces, and it will have an impact on the formation of city areas. The types of people who are more likely to use autonomous vehicles are not yet known, because this technology is still under development, and not on the market. Assumptions, surveys, and simulations can be used to predict the preferences of travellers and to assess the impact of AVs on their mobility. As a research approach, simulations of daily activity plans of three groups of travellers (long-travel travellers, AVs as feeder system of public transport, and travellers with specified characteristics) were studied through seven scenarios using MATSim open source software that has the capability to simulate various modes of transport at the microscopic level. The utility-related calculations were based on the Charypar-Nagel utility function, which applies the GA when generating new activity plans. Simulations with the current transport situations were simulated first, then each scenario was simulated with AVs. The results showed a reasonable reduction of travel time in all scenarios. It can be noted based on the results of Scenarios 1 and 3 that as travel time increases the required fleet size of $\mathrm{AVs}$ increases. Additionally, Scenarios 1 and 2 showed that the type of the composition of daily activity plans contributes to the determination of the required fleet size. It was also concluded that the travel time increases as the percentage of motorized transport mode increases. Additionally, Scenario 4 presented a reduction in the trip time compared to the existing condition, where the number of required fleet size of AVs was 425 to serve 2,000 travellers. In Scenario 5.1, the impact of AVs on travellers with car ownership was studied, when only motorized transport modes were replaced by AVs, while 5.2 studied the impact of AVs when all transport modes were replaced by AVs (including bike and walking). The results showed a difference in the required fleet size of AVs to serve the demand, and a reduction in the travel time was also presented. Simulation of 150 AVs was enough to meet the demand of Scenario 6, where people wanted to use personal cars. This scenario suggested replacing of 468 personal cars by only 150 AVs. Finally, Scenario 7 presented travellers who do not buy public transport monthly ticket, which means the cost of using public transport is relatively costly compared to the ones who own the monthly ticket. For those persons who would prefer to use $\mathrm{AVs}$ instead of public transport, the required fleet size to serve 2,240 travellers is $475 \mathrm{AVs}$.

In summary, the reduction in travel time was 13\% to $42 \%$ for group (a), $33 \%$ for group (b), and $16 \%$ to $28 \%$ for group (c) compared with the original travel times. The number of AVs required to serve the demand is less than the number of the existing conventional motorized transport modes, in case travellers would use personal cars. The acceptability of $\mathrm{AVs}$ depends on the level of trust that people give to this technology since there is no human driver who drives the car. Moreover, travel time, travel cost, and the acceptability of travellers to wait for a vehicle to pick them up, is another factor that affects using AVs. The fleet size determines the waiting time for an AV, as it gets larger as the waiting time gets smaller. Finally, AVs can be accepted as a transport mode by travellers based on the value of travel time of travellers, and whether this AV is affordable for the people, or only for certain groups.

\section{ACKNOWLEDGEMENT}

The research presented in this paper and carried out at the Budapest University of Technology and Economics has been supported by the National Research Development and Innovation Fund (TKP2020 Institution Excellence Subprogram, Grant No. BME-IE-MISC) based on the charter of bolster issued by the National Research Development and Innovation Office under the auspices of the Ministry for Innovation and Technology. The research was supported by the BKK Centre for Budapest Transport providing travel data collected through the EFM Unified Transport Model of Budapest.

JAMIL HAMADNEH, doktorandusz ${ }^{1}$

E-mail: jhamadneh@edu.bme.hu

DOMOKOS ESZTERGÁR-KISS, $\mathrm{PhD}^{1}$

E-mail: esztergar@mail.bme.hu

${ }^{1}$ Budapesti Műszaki és Gazdaságtudományi Egyetem Közlekedésüzemi és Közlekedésgazdasági Tanszék

Müegyetem rkp. 3, 1111 Budapest, Magyarország

\section{AZ UTAZÁSI IDŐ POTENCIÁLIS CSÖKKENTÉSE AUTONÓM JÁRMÜVEKKEL KÜLÖNBÖZÖ UTASCSOPORTOK SZÁMÁRA}

\section{ABSZTRAKT}

Az autonóm jármüveket várhatóan megváltoztatják az utazási szokásokat. Ezek a változások közlekedési modellek és szimulációs eszközök segitségével értelmezhetők. 
Ebben a cikkben a napi tevékenységi láncokat vizsgáltuk az utazási időminimalizálásánakcéljából autonómjármüvek segitségével. Három utascsoportot határoztunk meg annak alapján, hogy milyen elönyökkel járhat számukra az autonóm jármüvekkel történö utazás. A csoportok a következők: a) hosszú utazások; b) közösségi közlekedés és c) meghatározott jellemzökkel rendelkezö utasok. Az egyes csoportokhoz forgatókönyveket rendeltünk hozzá. Az összegyüjtött adatokból összesen hét forgatókönyvet készitettünk, melyeket két típusú szimulációval vizsgáltunk, a jelenlegi közlekedési módok szerint, illetve autonóm jármüvekkel. A szimulációkat a MATSim nevü alkalmazással végeztük. A MATSim-mel szimuláltuk a jelenlegi utazásokat és azokat, amelyeknél az autonóm jármüvek részben vagy teljesen kiváltják a hagyományos közlekedési módokat. Az eredmények alapján az utazási idö csökkent: az a) csoport esetében 13\%-ról 42\%-ra, a (b) csoport esetében 33\%-ra, és a (c) csoport esetében 16\%-28-ra az eredeti utazási időkhöz képest. Összegezve kijelenthetö, hogy az autonóm jármüvek minden esetben csökkentik az utazási idöt, ami elönyöket jelent az emberek számára a hatékonyság növekedésében.

\section{KULCSSZAVAK}

tevékenység alapú modellezés; autonóm jármüvek; tevékenységi láncok; optimalizálás; MATSim.

\section{REFERENCES}

[1] Krueger R, Rashidi TH, Rose JM. Preferences for shared autonomous vehicles. Transportation Research Part C: Emerging Technologies. 2016;69: 343-55. DOI: 10.1016/j.trc.2016.06.015

[2] Luo L, Parady GT, Takami K, Harata N. Evaluating the Impact of Autonomous Vehicles on Accessibility using Agent-Based Simulation: A Case Study of Gunma Prefecture. Journal of JSCE. 2019;7(1): 100-11. DOI: 10.2208/journalofjsce.7.1_100

[3] Al-Sahili K, Hamadneh J. Establishing parking generation rates/models of selected land uses for Palestinian cities. Transportation Research Part A: Policy Practice. 2016;91: 213-22. DOI: 10.1016/j.tra.2016.06.027

[4] Pudāne B, Molin EJ, Arentze TA, Maknoon Y, Chorus CG. A Time-use Model for the Automated Vehicle-era. Transportation Research Part C: Emerging Technologies. 2018;93: 102-14. DOI: 10.1016/j.trc.2018.05.022

[5] Levin MW, Boyles SD. Effects of autonomous vehicle ownership on trip, mode, and route choice. Transportation Research Record: Journal of the Transportation Research Board. 2015;2493: 29-38. DOI: 10.3141/2493-04

[6] Das S, Sekar A, Chen R, Kim HC, Wallington TJ, Williams E. Impacts of Autonomous Vehicles on Consumers Time-Use Patterns. Challenges. 2017;8(2): 32. DOI: 10.3390/challe8020032

[7] Liu T-L, Huang H-J, Yang H, Zhang X. Continuum modeling of park-and-ride services in a linear monocentric city with deterministic mode choice. Transportation Research Part B: Methodological. 2009;43(6): 692-707. DOI: $10.1016 / j$. trb.2009.01.001
[8] Yap MD, Correia G, Van Arem B. Preferences of travellers for using automated vehicles as last mile public transport of multimodal train trips. Transportation Research Part A: Policy and Practice. 2016;94: 1-16. DOI: 10.1016/j.tra.2016.09.003

[9] Steck F, Kolarova V, Bahamonde-Birke F, Trommer $\mathrm{S}$, Lenz B. How autonomous driving may affect the value of travel time savings for commuting. Transportation Research Record: Journal of the Transportation Research Board. 2018;2672(46): 10. DOI: 10.1177/0361198118757980

[10] HCSO. Population Census in 2011. Hungary: Hungarian Central Statistical Office (HCSO); 2018.

[11] Horni A, Nagel K, Axhausen KW. The multi-agent transport simulation MATSim. Ubiquity Press London; 2016. 620 p. DOI: $10.5334 /$ baw

[12] Castiglione J, Bradley M, Gliebe J. Activity-based travel demand models: A primer; 2015. DOI: 10.17226/22357

[13] Fagnant DJ, Kockelman KM. Dynamic ride-sharing and fleet sizing for a system of shared autonomous vehicles in Austin, Texas. Transportation. 2018;45(1): 143-58. DOI: $10.1007 / \mathrm{s} 11116-016-9729-\mathrm{z}$

[14] Anderson JM, Nidhi K, Stanley KD, Sorensen P, Samaras C, Oluwatola OA. Autonomous vehicle technology: A guide for policymakers: Rand Corporation; 2014. Available from: https://www.rand.org/pubs/research_reports/RR443-2.html

[15] Fosgerau M, editor. Automation and the value of time in passenger transport. International Transport Forum Discussion Papers. OECD Publishing; 2019. DOI: 10.1787/6efb6342-en

[16] Hao M, Yamamoto T, editors. Analysis on supply and demand of shared autonomous vehicles considering household vehicle ownership and shared use. 2017 IEEE 20th International Conference on Intelligent Transportation Systems (ITSC), Yokohama, Japan. IEEE; 2017. DOI: 10.1109/ITSC.2017.8317920

[17] Bischoff J, Maciejewski M. Simulation of city-wide replacement of private cars with autonomous taxis in Berlin. Procedia Computer Science. 2016;83: 237-44. DOI: 10.1016/j.procs.2016.04.121

[18] Fagnant DJ, Kockelman KM, Bansal P. Operations of shared autonomous vehicle fleet for Austin, Texas, market. Transportation Research Record: Journal of the Transportation Research Board. 2015;2536: 98-106. DOI: $10.3141 / 2536-12$

[19] Fagnant DJ, Kockelman K. Preparing a nation for autonomous vehicles: Opportunities, barriers and policy recommendations. Transportation Research Part A: Policy and Practice. 2015;77: 167-81. DOI: 10.1016/ j.tra.2015.04.003

[20] Ortega J, Hamadneh J, Esztergár-Kiss D, Tóth J. Simulation of the Daily Activity Plans of Travellers Using the Park-and-Ride System and Autonomous Vehicles: Work and Shopping Trip Purposes. Applied Sciences. 2020;10(8): 2912. DOI: 10.3390/app10082912

[21] Koryagin M. Urban planning: A game theory application for the travel demand management. Periodica Polytechnica Transportation Engineering. 2018;46(4): 171-8. DOI: 10.3311/PPtr.9410

[22] Litman T. Transportation Cost and Benefit Analysis. 
Victoria Transport Policy Institute; 2009. Available from: https://www.vtpi.org/tca/tca01.pdf

[23] Bozorg SL, Ali SM. Potential Implication of Automated Vehicle Technologies on Travel Behavior and System Modeling 2016. Available from: https://digitalcommons. fiu.edu/cgi/viewcontent. cgi?article=3999\& context=etd.

[24] Nicolai TW. Integrating an urban simulation model with a travel model. Berlin Institute of Technology (TU Berlin); 2013. Available from: http://webarchiv.ethz.ch/sustaincity/publications/WP_6.4_Warm_Hot_Start.pdf

[25] Tirachini A, Hensher DA, Rose JM. Multimodal pricing and optimal design of urban public transport: The interplay between traffic congestion and bus crowding. Transportation Research Part B: Methodological. 2014;61: 33-54. DOI: 10.1016/j.trb.2014.01.003

[26] Charypar D, Nagel K. Generating complete all-day activity plans with genetic algorithms. Transportation. 2005;32(4): 369-97. DOI: 10.1007/s11116-004-8287-y

[27] Man K-F, Tang K-S, Kwong S. Genetic algorithms: Concepts and applications [in engineering design]. IEEE transactions on Industrial Electronics. 1996;43(5): 51934. DOI: $10.1109 / 41.538609$

[28] Ghanea-Hercock R. Applied evolutionary algorithms in Java. Springer Science \& Business Media; 2013. DOI: 10.1007/978-0-387-21615-7

[29] Yang X-S. Nature-inspired optimization algorithms. Elsevier; 2014. DOI: 10.1016/C2013-0-01368-0

[30] Arnott R, De Palma A, Lindsey R. A structural model of peak-period congestion: A traffic bottleneck with elastic demand. The American Economic Review. 1993;83: 16179. Available from: https://www.jstor.org/stable/2117502

[31] Java OpenStreetMap. Trac Open Source Project; 2018. Available from: https://josm.openstreetmap.de/wiki/ Download\#Java

[32] TransitFeeds. BKK GTFS; 2018. Available from: https:// transitfeeds.com/p/bkk/42 [cited 8 November 2018].

[33] Poletti F, Bösch P, Ciari F, Axhausen K. Public transit route mapping for large-scale multimodal networks. ISPRS International Journal of Geo-Information. 2017;6(9): 268. DOI: 10.3390/ijgi6090268

[34] Bösch PM, Ciari F. Macrosim-a macroscopic MobSim for MATSim. Procedia Computer Science. 2017;109: 861-8. DOI: 10.1016/j.procs.2017.05.406

[35] MATSim Community. Mutli-Agent Transport Simulation MATSim Community 2018. Available from: http://ci.matsim.org:8080/job/MATSim_contrib_M2/ws/contribs/av/ target/site/apidocs/index.html

[36] Hamadneh J, Esztergár-Kiss D, editors. Impacts of Shared Autonomous Vehicles on the Travellers' Mobility. 2019 $6^{\text {th }}$ International Conference on Models and Technolo- gies for Intelligent Transportation Systems (MT-ITS), Poland. IEEE; 2019. DOI: 10.1109/MTITS.2019.8883392

[37] GmbH B. Taxi fares are based on the current taxi tariffs of Budapest 2019. Available from: https://www.bettertaxi.com/taxi-fare-calculator/budapest/

[38] Simoni MD, Kockelman KM, Gurumurthy KM, Bischoff J. Congestion Pricing in a World of Self-driving vehicles: An Analysis of Different Strategies in Alternative Future Scenarios. Transportation Research Part C: Emerging Technologies. 2018;98: 167-85. DOI: 10.1016/ j.trc.2018.11.002

[39] Boesch PM, Ciari F, Axhausen KW. Autonomous vehicle fleet sizes required to serve different levels of demand. Transportation Research Record: Journal of the Transportation Research Board. 2016. p. 111-9. DOI: $10.3141 / 2542-13$

[40] Maciejewski M, Nagel K, editors. Towards multi-agent simulation of the dynamic vehicle routing problem in matsim. International Conference on Parallel Processing and Applied Mathematics. Springer; 2011. DOI: 10.1007/978-3-642-31500-8_57

[41] Maciejewski M, Horni A, Nagel K, Axhausen K. Dynamic Transport Services. The Multi-Agent Transport Simulation MATSim;10.5334/baw.23. London: Ubiquity; 2016. p. 145-52. DOI: 10.5334/baw.23

[42] Bischoff J, Führer K, Maciejewski M. Impact assessment of autonomous DRT systems. Transportation Research Procedia. 2018:1-8.

[43] Herbawi WM, Weber M, editors. A genetic and insertion heuristic algorithm for solving the dynamic ridematching problem with time windows. Proceedings of the $14^{\text {th }}$ Annual Conference on Genetic and Evolutionary Computation. ACM: 2012. DOI: 10.1145/2330163.2330219

[44] Childress S, Nichols B, Charlton B, Coe S. Using an activity-based model to explore the potential impacts of automated vehicles. Transportation Research Record. 2015;2493(1): 99-106. DOI: 10.3141/2493-11

[45] Greenblatt JB, Shaheen S. Automated vehicles, on-demand mobility, and environmental impacts. Current Sustainable/Renewable Energy Reports. 2015;2(3): 74-81. DOI: $10.1007 / \mathrm{s} 40518-015-0038-5$

[46] Brown A, Gonder J, Repac B. An analysis of possible energy impacts of automated vehicles. Road vehicle automation. Springer; 2014. p. 137-53. DOI: 10.1007/9783-319-05990-7_13

[47] Calvert S, Schakel W, Van Lint J. Will automated vehicles negatively impact traffic flow? Journal of Advanced Transportation. 2017; Article ID 3082781. DOI: $10.1155 / 2017 / 3082781$ 